УДК 628.162

\author{
${ }^{[0000-0001-5287-3733]}$ Г. С. Столяренко, д.m.н., профессор, \\ e-mail: radikal@ukr.net \\ Т. С. Черний, аспирантка, \\ e-mail: cherniy.tajaija@ukr.net \\ ${ }^{[0000-0001-6587-6677] ~ Н . ~ М . ~ Ф о м и н а, ~ с т а р и и и ̆ ~ п р е п о д а в а т е л ь, ~}$ \\ e-mail: n_fomina@ukr.net
}

А. И. Шморгун, студентка

e-mail: alina13shmorgun@gmail.com

Черкасский государственный технологический университет

б-р Шевченко, 460, г. Черкассы, 18006, Украина

\title{
ГИДРОМЕТАЛЛУРГИЧЕСКАЯ ТЕХНОЛОГИЯ ПЕРЕРАБОТКИ ЦИНКСОДЕРЖАЩИХ ШЛАМОВ СТОЧНЫХ ВОД ПРОИЗВОДСТВА ХИМВОЛОКНА
}

В работе представлен гидрометаллургический способ переработки ичинкосодержащего илама сточных вод методом выщелачивания. Извлечение иинка из шлама является актуальной темой для экологической безопасности города Черкассы и Украины в иелом, а также для сферы производства удобрений для аграрных стран. Для изучения гранулометрического состава исходной руды был выбран метод мокрого грохочения. Проведен фазовый химический анализ на формы нахождения ичика. Для изучения вещественного состава пробы шламов были применены рентгеноструктурный и термогравиметрический анализы. Проведена серия опытов на полупромышленной установке, изучено влияние температуры, соотношения компонентов и времени на выход продукта. Разработана технологическая схема.

Ключевые слова: выщелачивание, иинк, илам, полупромышленная установка, сочиальный эффект, эколого-экономические расчеты.

Введение. В шламонакопителях целлюлозных производств накоплено более 6000 тыс. тонн цинксодержащих шламов, образованных в результате известковой очистки стоков.

Для их переработки исследователями Украины и России были предложены различные технологические схемы с применением как пирометаллургических, так и гидрометаллургических процессов [1-3].

В рамках данной работы представлены результаты опытно-промышленных испытаний технологической схемы, в основе которой лежат процессы щелочного выщелачивания цинка.

Краткая характеристика исходного сырья. Проба материала для проведения исследований была поставлена в количестве 2000 кг (5 биг-бегов).

Для определения химического состава, физико-механических свойств, а также для проведения лабораторных исследований была отобрана средняя проба шламов. Влажность шламов составила $66,9 \%$, удельный вес $2,374 \mathrm{r} / \mathrm{cm}^{3}$.

Результаты химического анализа пробы шламов приведены в таблице 1.

Гранулометрический состав исходной руды определялся методом мокрого грохочения материала через сита с размером ячеек 1,$0 ; 0,63 ; 0,315 ; 0,160$ и 0,071 мм. Гранулометрический состав фракции минус 0,071 мм определялся на лазерном анализаторе «ANALYSETTE 22» фирмы FRITSCH. Результаты гранулометрического анализа методом мокрого грохочения исходной руды приведены в таблице 2, результаты анализа фракции минус 0,071 мм на лазерном анализаторе - в таблице 3 .

Распределение частиц при определении гранулометрического состава исходной пробы минус 0,071 мм изображено на рисунке 1. 
Таблица 1 - Результаты химического анализа шлама

\begin{tabular}{|c|c|c|c|}
\hline $\begin{array}{c}\text { Компо- } \\
\text { нент }\end{array}$ & $\begin{array}{c}\text { Содер- } \\
\text { жание, \% }\end{array}$ & $\begin{array}{c}\text { Ком- } \\
\text { понент }\end{array}$ & $\begin{array}{c}\text { Содер- } \\
\text { жание, \% }\end{array}$ \\
\hline $\mathrm{Cu}$ & 0,048 & $\mathrm{Mg}$ & 0,96 \\
\hline $\mathrm{Zn}$ & 8,15 & $\mathrm{Mn}$ & 0,096 \\
\hline $\mathrm{Pb}$ & 0,020 & $\mathrm{Al}$ & 1,46 \\
\hline $\mathrm{Fe}$ & 6,47 & $\mathrm{Ca}$ & 16,0 \\
\hline $\mathrm{S}_{\text {общ }}$ & 2,03 & $\mathrm{C}_{\text {общ }}$ & 11,55 \\
\hline $\mathrm{S}_{\text {сульфат }}$ & $<0,1$ & $\mathrm{C}_{\text {карбон }}$ & 5,8 \\
\hline $\mathrm{Na}$ & 0,42 & $\mathrm{Ti}$ & 0,034 \\
\hline $\mathrm{K}$ & 0,22 & $\mathrm{SiO}_{2}$ & 23,04 \\
\hline $\mathrm{Cl}$ & $<0,05$ & & \\
\hline
\end{tabular}

Таблица 2 - Результаты гранулометрического ситового анализа

\begin{tabular}{|l|l|}
\hline $\begin{array}{l}\text { Класс крупности, } \\
\text { мм }\end{array}$ & Выход, \% \\
\hline$+1,0$ & 1,72 \\
\hline$-1,0+0,63$ & 0,86 \\
\hline$-0,63+0,315$ & 6,05 \\
\hline$-0,315+0,160$ & 9,95 \\
\hline$-0,160+0,071$ & 17,12 \\
\hline$-0,071$ & 64,30 \\
\hline Итого: & 100,00 \\
\hline
\end{tabular}

Таблица 3 - Сводные результаты гранулометрического анализа пробы шламов

\begin{tabular}{|c|c|}
\hline Класс крупности, мм & Выход, $\%$ \\
\hline$+1,0$ & 1,72 \\
\hline$-1,0+0,63$ & 0,86 \\
\hline$-0,63+0,315$ & 6,05 \\
\hline$-0,315+0,160$ & 9,95 \\
\hline$-0,160+0,071$ & 17,12 \\
\hline$-0,071+0,045$ & 8,86 \\
\hline$-0,045+0,038$ & 2,54 \\
\hline$-0,038+0,020$ & 15,40 \\
\hline$-0,020+0,010$ & 15,13 \\
\hline$-0,010+0,005$ & 7,96 \\
\hline$-0,005+0,001$ & 11,41 \\
\hline$-0,001$ & 3,00 \\
\hline Итого & 100,00 \\
\hline
\end{tabular}

Результаты фазового химического анализа пробы шлама на формы нахождения цинка приведены в таблице 4. Для изучения вещественного состава пробы материала, поставленного для проведения исследований, были также применены рентгеноструктурный и термогравиметрический анализы.

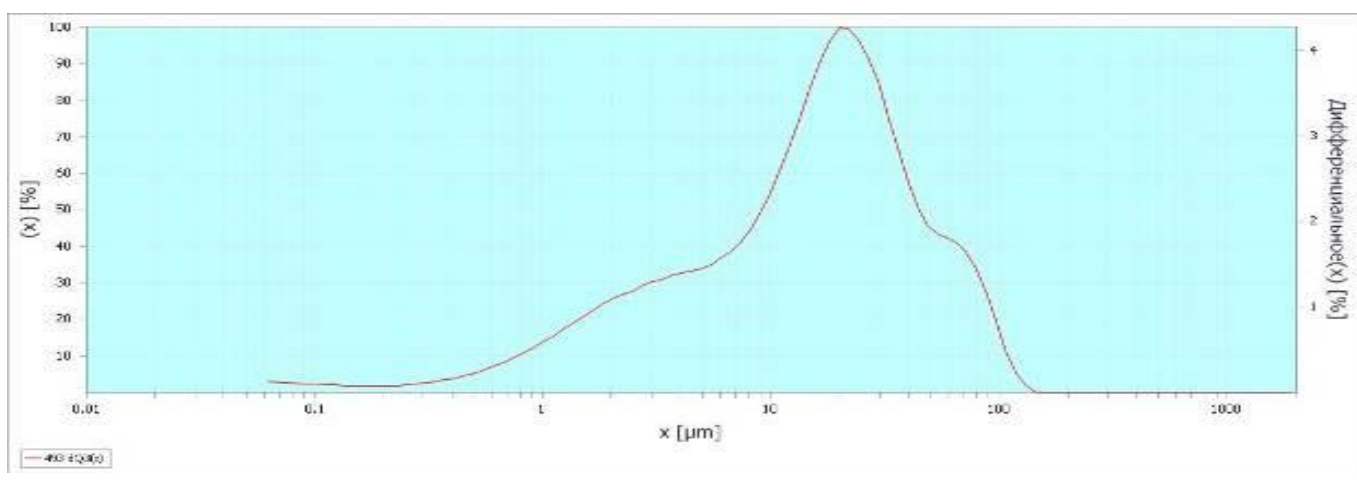

Рисунок 1 - Распределение частиц при определении гранулометрического состава исходной пробы минус 0,071 мм

Дифрактограмма приведена на рисунке 2, результаты термогравиметрического анализа - на рисунке 3.

Эксперименты проводили при максимальном нагреве температуры до $1050^{\circ} \mathrm{C}$ со скоростью 15 град/мин в потоке воздуха. В процессе нагрева параллельно фиксировались тепловые эффекты на кривой DSC и изменения массы образца - на кривой TGA.

Таблица 4 - Результаты фазового химического анализа шлама на формы нахождения цинка

\begin{tabular}{|c|c|c|}
\hline \multirow{2}{*}{ Наименование } & \multicolumn{2}{|c|}{ Содержание, \% } \\
\hline & абс. & OTH. \\
\hline Сульфат цинка & 0,09 & 1,1 \\
\hline Карбонаты, силикаты и оксиды цинка & 5,36 & 65,8 \\
\hline Сульфид цинка & 2,61 & 32,0 \\
\hline Цинк в алюмосиликатах & 0,09 & 1,1 \\
\hline Суммарно & 8,15 & 100,0 \\
\hline
\end{tabular}

(C Г. С. Столяренко, Т. С. Черний, Н. М. Фомина, А. И. Шморгун, 2019 DOI: $10.24025 / 2306-4412.3 .2019 .178607$ 


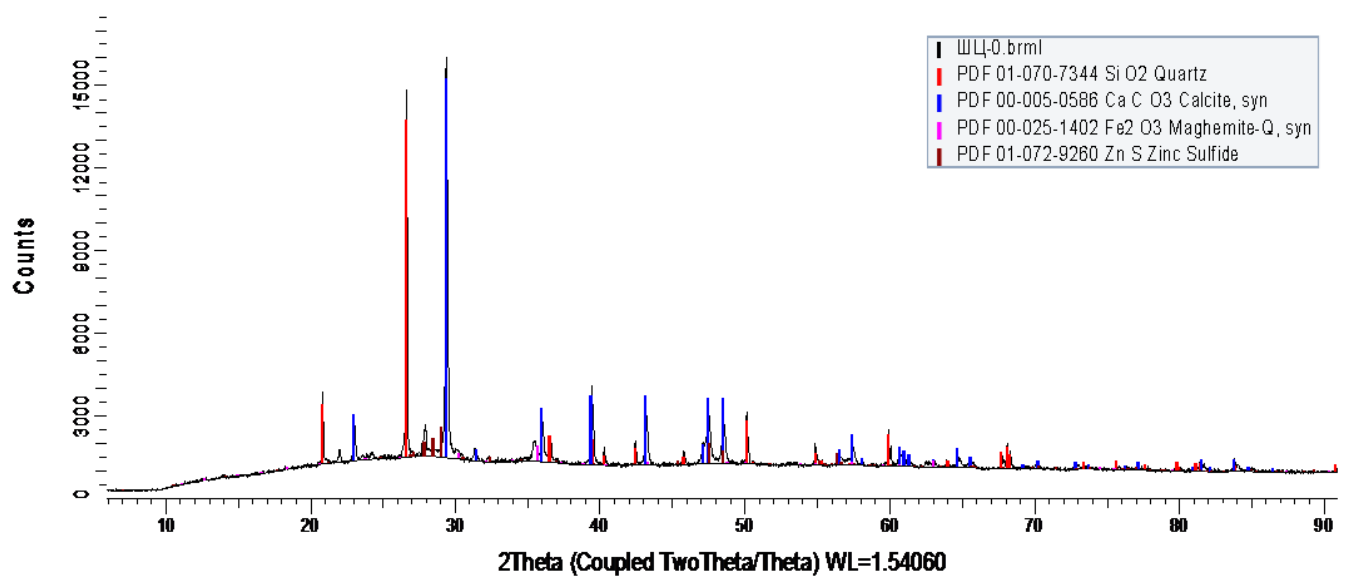

Рисунок 2 - Дифрактограмма пробы цинкового шлама

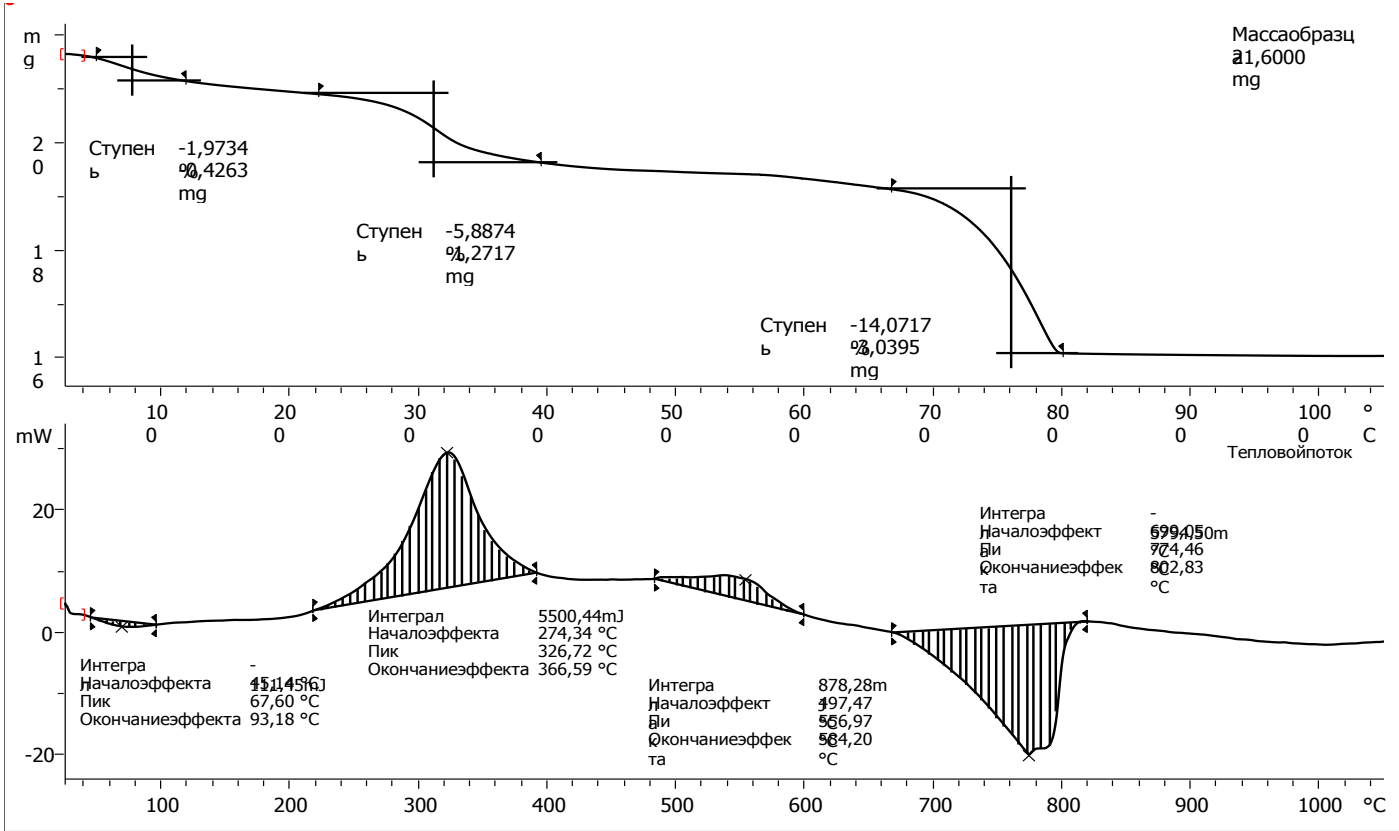

Рисунок 3 - Результаты термогравиметрического исследования пробы цинкового шлама на приборе синхронного термического анализа фирмы METTLERTOLED

В интервале температур $45 \div 95^{0} \mathrm{C}$ происходит удаление адсорбированной воды (до $2 \%)$. Значительный экзотермический эффект в интервале температур $275 \div 370^{\circ} \mathrm{C}$ характерен для сгорания органических соединений. Потеря массы образца составила 5,9\%. В интервале температур $497 \div 584^{\circ} \mathrm{C}$ отмечен незначительный экзотермический эффект, что соответствует окислению сульфидов. Эндотермический эффект со значительной потерей веса (порядка $14 \%$ отмечен в интервале температур $699 \div 802^{\circ} \mathrm{C}$. Это характерно для разложения карбонатных форм. При дальнейшем на- греве пробы до $1050^{\circ} \mathrm{C}$ на кривой теплового потока эффектов нет.

Описание технологической и аппаратурной схемы переработки шламов. Технологическая схема переработки шламов на рисунке 4 была разработана представителямиавторами и описана в Регламенте на проведение испытаний.

Для реализации схемы на опытнопромышленной установке было подготовлено соответствующее оборудование и комплектующие.

Аппаратурная схема приведена на рисунке 5. 


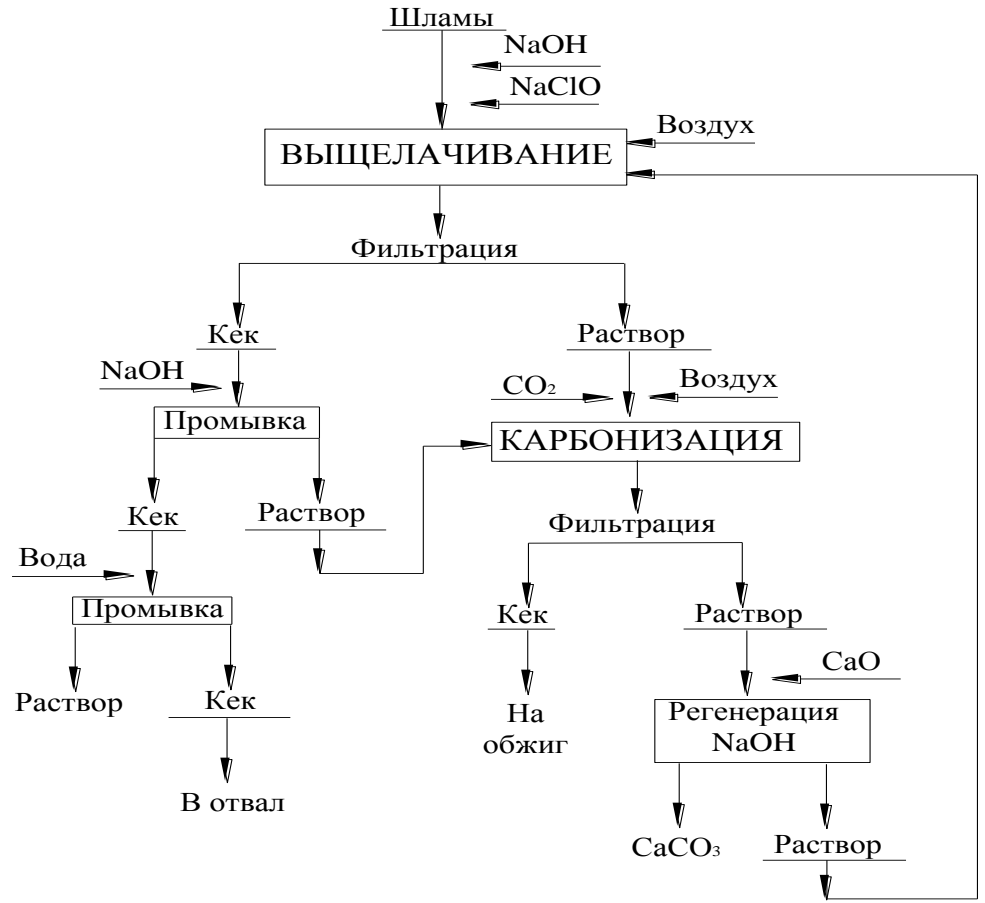

Рисунок 4 - Технологическая схема гидрометаллургической переработки шламов

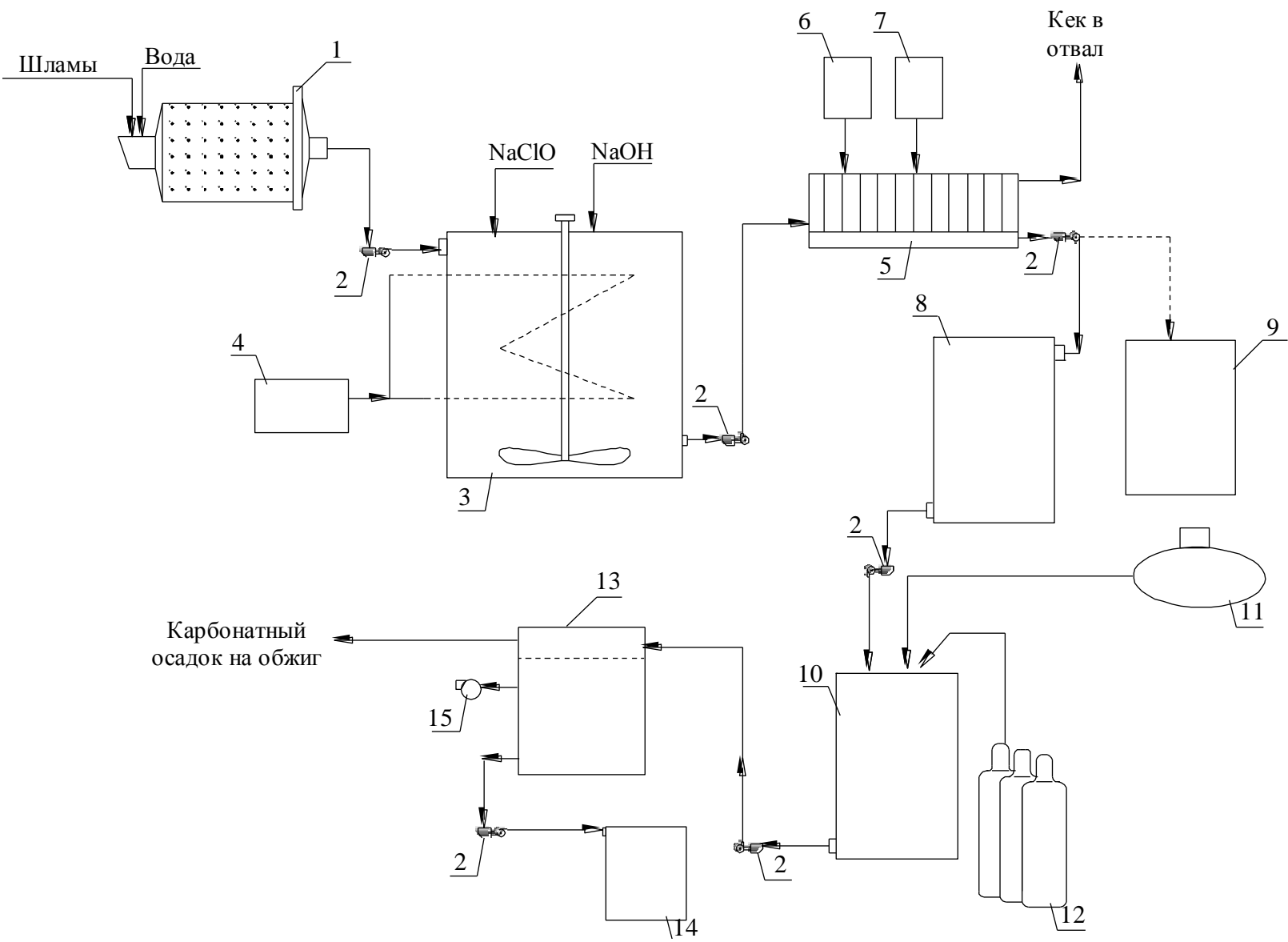

1 - шаровая мельница, 2 - насос, 3 - бак выщелачивания, 4 - компрессор, 5 - фильтр-пресс, 6 - бак с NaOH, 7 - бак с водой, 8 - бак-накопитель, 9 - бак с промывной водой, 10 - бак карбонизации, 11 - компрессор, 12 - баллоны с $\mathrm{CO}_{2}, 13$ - нутч-фильтр, 14 - бак-накопитель

Рисунок 5 - Аппаратурная схема процесса проведения испытаний

(C) Г. С. Столяренко, Т. С. Черний, Н. М. Фомина, А. И. Шморгун, 2019 DOI: $10.24025 / 2306-4412.3 .2019 .178607$ 
Описание основного оборудования. Шаровая мельница: объем 100 дм³ $^{3}$ Регулировка количества об/мин 2,2 кВт. Оснащена приёмным баком с мешалкой и насосом для откачки измельчённой пульпы.

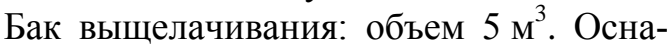
щён: 1) мешалка с регулируемым числом об/мин, 3,7 кВт; 2) циркуляционный насос; 3) змеевики для циркуляции с горячей водой от бака-бойлера для нагрева пульпы; 4) аэрационное кольцо для распределения воздуха от компрессора. Производительность компрессора - $5 \mathrm{~m}^{3} /$ мин; 5) датчики температуры; 6) уровнемеры; 7) центробежный насос для откачки пульпы из бака. Производительность насоса - 50 дм $^{3} /$ мин х 40 м.

Фильтр-пресс. Автоматический фильтрпресс компрессионного типа. Площадь фильтрации $-6,5 \mathrm{~m}^{2}$. Оснащён компрессором, баками-сборниками фильтрата, бакомсборником промывной воды и соответствующими насосами.

Установка для карбонизации. Объем бака $-0,5$ м$^{3}$. Оснащён: 1) баллоны с $\mathrm{CO}_{2}$; 2) компрессор; 3) погружной насос для откачки пульпы; 4) pH-метр.

Нутч-фильтр. Диаметр - 1,2 м. Оснащен вакуумным насосом (400 мм рт.ст.) и насосом для откачки фильтрата.

Подготовка шламов к выщелачиванию. Измельчение шламов осуществлялось в шаровой мельнице периодического действия при продолжительности 15 минут.

Соотношение Ж:Т на стадии измельчения было 3,5:1. При меньшем соотношении Ж:Т шламы залипали на шарах и не подлежали разгрузке. Гранулометрический состав шламов после операции измельчения приведён в таблице 5. Измельчённая пульпа шламов дополнительно разбавлялась и перекачивалась в бак-агитатор для последующего выщелачивания.

Таблица 5 - Гранулометрический состав шлама после шаровой мельницы

\begin{tabular}{|c|c|}
\hline Класс крупности, мм & Выход, $\%$ \\
\hline$+0,63$ & 0,35 \\
\hline$-0,63+0,315$ & 0,71 \\
\hline$-0,35+0,16$ & 4,16 \\
\hline$-0,16+0,071$ & 14,88 \\
\hline$-0,071$ & 79,90 \\
\hline Итого & 100,0 \\
\hline
\end{tabular}

Разбавление требовалось для снижения вязкости пульпы с целью прокачивания по системе трубопроводов без их закупоривания.

Вышелачивание шламов. Для выполнения первой операции по выщелачиванию было измельчено 500 кг шламов (по сухому) и в виде водной пульпы с соотношением Ж:T=4,5:1 перекачано в бак-агитатор. В пульпу были добавлены $\mathrm{NaOH}$ (292 кг) и вода $\left(\sim 0,25 \mathrm{~m}^{3}\right)$ для соблюдения требуемых разработчиком технологии условий (Приложение В - Ответы на вопросы по проведению испытаний). Общий объём пульпы составил $\sim 2,75 \mathrm{~m}^{3}$ (в том числе объём жидкой части $\left.\sim 2,54 \mathrm{M}^{3}\right)$.

Затем был включен нагрев бака и аэрирование пульпы.

После нагрева пульпы до $60^{\circ} \mathrm{C}$ через 1 час был осуществлён отбор пробы пульпы. Содержание цинка в жидкой фазе пульпы составило 4,22 г/дм³ ${ }^{3}$. Поскольку это было значительно меньше ожидаемого (при планируемом извлечении $\sim 70-75 \%$ содержание цинка в растворе ожидалось на уровне 11,412,2 г/дм $\left.{ }^{3}\right)$, выщелачивание было продолжено. Через четыре часа в пульпу было добавлено 60 дм $^{3}$ гипохлорита натрия с содержанием активного хлора 140 г/дм³ ${ }^{3}$ Через один час после добавления гипохлорита натрия нагрев пульпы был отключен, а перемешивание и аэрация пульпы были продолжены. Результаты выщелачивания приведены в таблице 6 . Извлечение цинка при выщелачивании не превысило 39,3\%.

В связи с низким извлечением цинка при выщелачивании шламов на опытнопромышленной установке были поставлены тесты в лабораторных условиях с дублированием и ужесточением условий выщелачивания шламов: с повышением температуры процесса до $90^{\circ} \mathrm{C}$ и концентрации $\mathrm{NaOH}$ в растворе до 200 г/дм ${ }^{3}$. Результаты тестов приведены в таблице 7.

Результаты лабораторных тестов при условиях, аналогичных условиям выщелачивания шламов на опытно-промышленной установке (температура $-60^{\circ} \mathrm{C}$, начальная концентрация $\mathrm{NaOH}-110-115$ г/дм ${ }^{3}$ ), согласуются с результатами испытаний. При повышении температуры и начальной концентрации щелочи извлечение цинка в раствор повышается, однако в выполненных тестах не превысило 52,0\%. 
Таблица 6 - Результаты выщелачивания шламов на опытно-промышленной установке ВНИИцветмета

\begin{tabular}{|c|c|c|c|c|c|c|c|}
\hline \multirow{3}{*}{ № } & \multirow{3}{*}{$\begin{array}{c}\text { Продолжитель- } \\
\text { ность выщела- } \\
\text { чивания, час }\end{array}$} & \multirow{3}{*}{$\mathrm{T},{ }^{\circ} \mathrm{C}$} & \multicolumn{4}{|c|}{ Жидкая часть пульпы } & \multirow{3}{*}{$\begin{array}{c}\text { Извлечение } \\
\text { цинка в рас- } \\
\text { твор, \% }\end{array}$} \\
\hline & & & \multirow{2}{*}{$\begin{array}{c}\gamma, \\
\Gamma / \mathrm{cm}^{3}\end{array}$} & \multicolumn{3}{|c|}{ Содержание в растворе } & \\
\hline & & & & $\begin{array}{l}\mathrm{NaOH}, \\
\Gamma / \text { дм }^{3}\end{array}$ & $\begin{array}{c}\mathrm{Na}_{2} \mathrm{CO}_{3}, \\
\Gamma / \mathrm{MM}^{3}\end{array}$ & $\mathrm{Zn}$, г/дм ${ }^{3}$ & \\
\hline 1 & 1 & 60 & 1,122 & 100,04 & 14,31 & 4,22 & 26,3 \\
\hline 2 & 2 & 62 & 1,116 & 94,8 & 31,8 & 4,34 & 27,1 \\
\hline 3 & 3 & 63 & 1,120 & 93,2 & 32,86 & 4,30 & 26,8 \\
\hline 4 & 4 & 62 & 1,121 & 92,4 & 32,86 & 5,50 & 34,3 \\
\hline 5 & 5 & 61 & 1,121 & 88,0 & 32,86 & 5,94 & 37,0 \\
\hline 6 & 24 & 42 & 1,136 & 97,6 & 40,28 & 6,30 & 39,3 \\
\hline 7 & 48 & 35 & 1,136 & 97,6 & 40,28 & 6,30 & 39,3 \\
\hline
\end{tabular}

Таблица 7 - Результаты лабораторных тестов по выщелачиванию шламов

\begin{tabular}{|c|c|c|c|c|c|c|}
\hline \multirow[b]{2}{*}{ № } & \multicolumn{2}{|c|}{ Условия выщелачивания } & \multirow{2}{*}{$\begin{array}{c}\text { Содержание } \\
\mathrm{Zn} \text { в растворе, } \\
\text { г/дм }^{3}\end{array}$} & \multirow{2}{*}{$\begin{array}{c}\text { Выход } \\
\text { кека, \% }\end{array}$} & \multirow{2}{*}{$\begin{array}{l}\text { Содержание } \\
\text { Zn в промы- } \\
\text { том кеке, \% }\end{array}$} & \multirow{2}{*}{$\begin{array}{c}\text { Извлечение } \\
\text { Zn в рас- } \\
\text { твор, \% }\end{array}$} \\
\hline & $\mathrm{t},{ }^{\circ} \mathrm{C}$ & $\mathrm{C}_{\mathrm{NaOH}}, \mathrm{\Gamma} / \mathrm{дM}^{3}$ & & & & \\
\hline 1 & 60 & 110,6 & 5,58 & 98,7 & 5,41 & 54,5 \\
\hline 2 & 60 & 210,4 & 7,20 & 99,4 & 4,53 & 74,8 \\
\hline 3 & 90 & 210,4 & 8,4 & 99,2 & 3,94 & 72,0 \\
\hline
\end{tabular}

В связи с ограниченным временем выполнения испытаний дополнительных тестов по изучению причин низкого извлечения цинка не проводилось. В связи с неудовлетворительными результатами выщелачивания последующие исследования по согласованию с Заказчиком выполнялись в объёме, отличающемся от первоначально планируемого при соответствующем сокращении объёма финансирования.

Фильтрация пульпы выщелачивания. Фильтрация пульпы выщелачивания осуществлялось на автоматическом фильтрпрессе компрессионного типа с площадью фильтрации 6,5 м² (таблица 6). Результаты испытаний показали, что скорость фильтрации не превысила даже в начальный период выщелачивания величины $0,037 \mathrm{~m}^{3} /\left(\mathrm{m}^{2} \cdot\right.$ час) (рисунок 6). Затем скорость фильтрации постепенно снижалась и через 15-20 минут практически полностью прекращалась. Всего было проведено 10 операций фильтрации. При разгрузке фильтра было отмечено, что толщина осадка на фильтровальных полотнах не превышала 20 мм. Влажность кека колебалась от 70 до $90 \%$.
Операцию промывки осадка на опытнопромышленной установке не проводили. Промывку осадка осуществляли в лабораторном масштабе с целью отбора пробы для проведения химического анализа. Промывка осуществлялась последовательно щелочным и водным растворами при Ж:Т=4:1 при 30 минутах перемешивания в лабораторном агитаторе.

Гранулометрический состав промытого кека выщелачивания приведён в таблице 8, результаты химического анализа - в таблице 9.

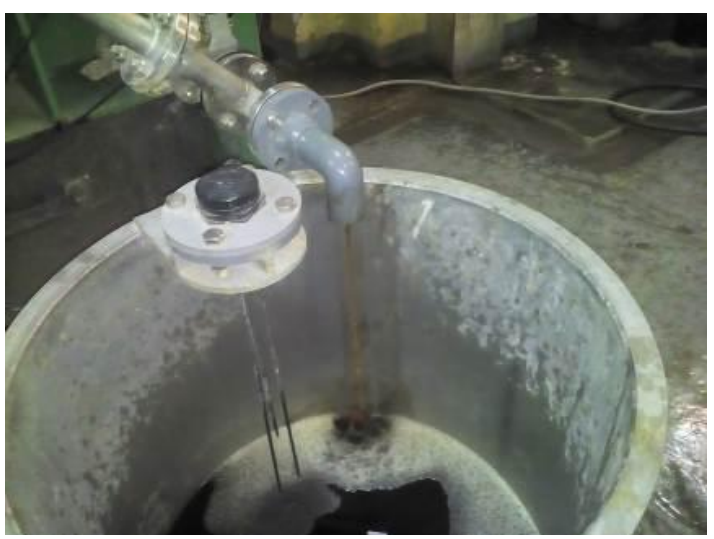

Рисунок 6 - Промежуточный бак-сборник фильтрата в первые 5 минут фильтрации пульпы выщелачивания 
Таблица 8 - Гранулометрический состав кека выщелачивания

\begin{tabular}{|c|c|}
\hline Класс крупности, мм & Выход, $\%$ \\
\hline$+0,63$ & 0,08 \\
\hline$-0,63+0,315$ & 0,53 \\
\hline$-0,35+0,16$ & 3,38 \\
\hline$-0,16+0,071$ & 12,28 \\
\hline$-0,071$ & 83,73 \\
\hline Итого & 100,0 \\
\hline
\end{tabular}

Таблица 9 - Результаты химического анализа кека выщелачивания

\begin{tabular}{|c|c|}
\hline Компонент & Содержание, $\%$ \\
\hline $\mathrm{Zn}$ & 4,07 \\
\hline $\mathrm{Fe}$ & 6,73 \\
\hline $\mathrm{SiO}_{2}$ & 23,9 \\
\hline $\mathrm{Ca}$ & 16,52 \\
\hline $\mathrm{Na}$ & 12,8 \\
\hline
\end{tabular}

По данным химического анализа содержание цинка в кеке после промывки составило $4,07 \%$. Содержание цинка в промывном щелочном растворе составило 6,2 г/дм ${ }^{3}$, в водном - 2,9 г/дм ${ }^{3}$.Можно считать, что на операции щелочной промывки не только удаляется маточный раствор из кека выщелачивания, но и происходит дополнительное извлечение цинка.

Извлечение цинка после выщелачивания и двухстадийной промывки составляет 52,0 \% при выходе кека выщелачивания $96 \%$.

Осаждение цинка из раствора выщелачивания. После фильтрации пульпы выщелачивания было получено $\sim 1,5 \mathrm{~m}^{3}$ с содержанием цинка 6,3 г/дм³ ${ }^{3}$ Всего было проведено три операции осаждения цинка на специально подготовленной установке (таблица 10).
Осаждение цинка осуществлялось продувкой через раствор выщелачивания углекислого газа из баллонов со сжатым газом. Также в раствор подавался воздух. Вид сверху пульпы карбонизации приведён на рисунке 7.

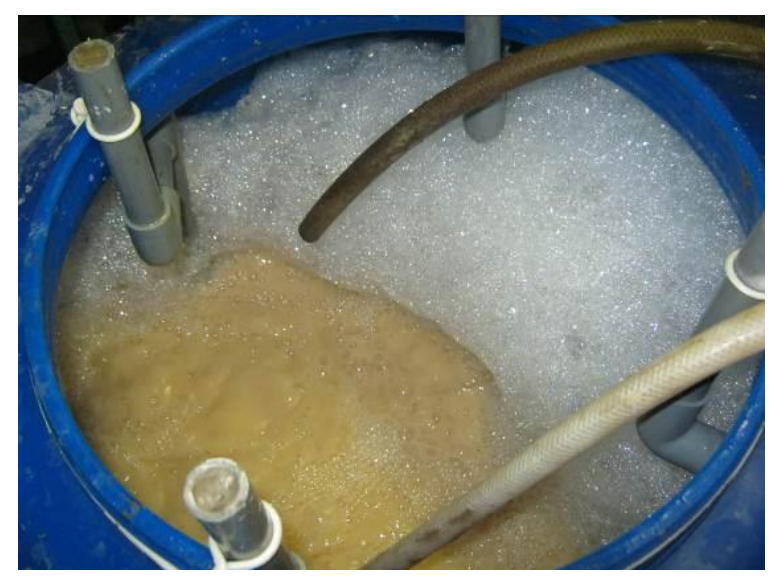

Рисунок 7 - Пульпа карбонизации (вид сверху)

При отработке условий операции каждый час отбирались пробы пульпы, в жидкой части которой определяли содержание цинка, $\mathrm{NaOH}$ и $\mathrm{Na}_{2} \mathrm{CO}_{3}$. Осуществлялся контроль температуры и рН пульпы. Результаты проведения первой операции приведены в таблице 10 . В соответствии с Регламентом процесс карбонизации необходимо было вести, пропуская углекислый газ до $\mathrm{pH}=9$. Однако, как видно из данных таблицы, осаждение цинка практически закончилось через 3 часа ведения процесса при $\mathrm{pH}=11,2$. При проведении дальнейших операций $\mathrm{pH}$ продолжали контролировать, однако сигналом окончания процесса считали снижение концентрации $\mathrm{NaOH}$ до $<10$ г/дм ${ }^{3}$.

Таблица 10 - Результаты первой операции осаждения цинка на опытнопромышленной установке ВНИИцветмета

\begin{tabular}{|c|c|c|c|c|c|c|c|}
\hline \multirow{2}{*}{ № } & $\begin{array}{c}\text { Продолжитель- } \\
\text { ность карбониза- } \\
\text { ции, час }\end{array}$ & \multicolumn{7}{|c|}{ С, ${ }^{\circ} \mathrm{C}$} & $\gamma, \Gamma / \mathrm{cm}^{3}$ & $\mathrm{pH}$ & $\begin{array}{c}\mathrm{NaOH}, \\
\Gamma^{3} \text { дм }^{3}\end{array}$ & $\begin{array}{c}\mathrm{Na}_{2} \mathrm{CO}, \\
\text { г/дм }\end{array}$ & $\begin{array}{c}\mathrm{Zn}, \\
\text { Г/дм }\end{array}$ \\
\hline 1 & 1 & 33 & 1,100 & 12,2 & 70,4 & 34,98 & 6,10 \\
\hline 2 & 2 & 40 & 1,119 & 12,4 & 30,8 & 48,76 & 5,87 \\
\hline 3 & 3 & 47 & 1,117 & 11,2 & 6,8 & 115,54 & 0,019 \\
\hline 4 & 4 & 47 & 1,118 & 10,5 & 6,8 & 124,02 & 0,36 \\
\hline 5 & 5 & 45 & 1,116 & 10,1 & - & 128,26 & 0,45 \\
\hline 6 & 6 & 44 & 1,120 & 9,7 & - & 131,44 & 0,58 \\
\hline
\end{tabular}


Пульпа карбонизации погружным насосом перекачивалась на нутч-фильтр. Скорость фильтрации пульпы была достаточно высокой и составила $0,87 \mathrm{~m}^{3} /\left(\mathrm{M}^{2} \cdot\right.$ час). Для промывки осадка после окончания фильтрации была добавлена вода 20 дм $^{3}$. Изображение осадка на фильтре по окончанию фильтрации и промывки приведено на рисунке 8.

Всего было получено 190 кг влажного осадка (30,5 кг сухого).

Результаты химического анализа осадка приведены в таблице 11.

Таблица 11 - Результаты химического анализа карбонатного цинкового осадка

\begin{tabular}{|c|c|}
\hline Компонент & Содержание, $\%$ \\
\hline $\mathrm{Zn}$ & 42,74 \\
\hline $\mathrm{Na}$ & 12,8 \\
\hline $\mathrm{C}$ & 6,5 \\
\hline
\end{tabular}

Осадок высушивался при температуре $95^{\circ} \mathrm{C}$ и передавался на операцию обжига.

Обжиг карбонатного цинкового осадка

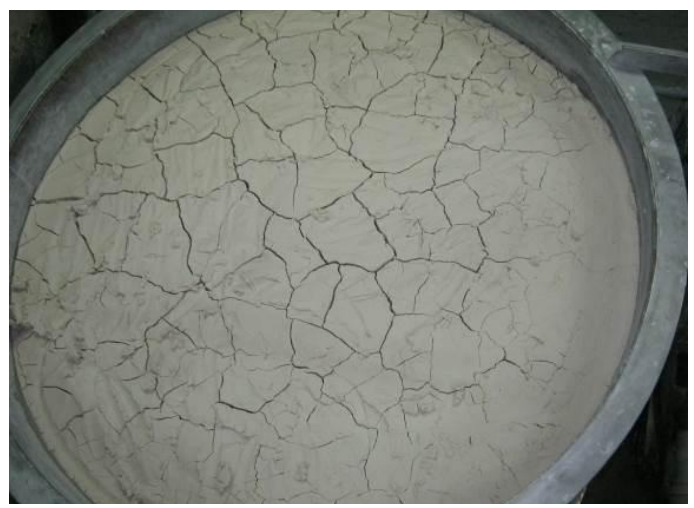

Рисунок 8 - Внешний вид карбонатного осадка цинка на фильтре
Обжиг материала проводили в лабораторной муфельной печи «Снол-1100». Материал загружали в шамотные лодочки размерами $230 \times 140 \times 30$ мм, толщина слоя материала в лодочке составляла 20 мм (рисунок 9).

Лодочку с навеской материала загружали в разогретую до $500^{\circ} \mathrm{C}$ печь и после стабилизации температуры печи засекали время обжига. По завершению времени лодочку доставали и охлаждали, затем взвешивали обожженный продукт. Результаты предварительных экспериментов приведены в таблице 12.

Фотографии материала, обожжённого при различной продолжительности обжига, приведены на рисунке 10.

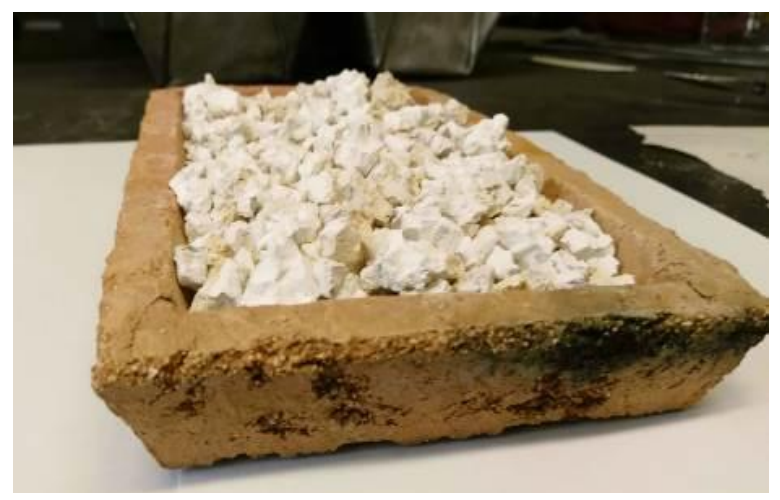

Рисунок 9 - Карбонатный цинковый осадок перед обжигом

Таблица 12 - Результаты обжига карбонатного осадка цинка при температуре $500^{\circ} \mathrm{C}$

\begin{tabular}{|c|c|c|c|c|c|c|}
\hline $\begin{array}{c}\text { № } \\
\text { опыта }\end{array}$ & $\begin{array}{c}\text { Продолжи- } \\
\text { тельность, } \\
\text { мин. }\end{array}$ & $\begin{array}{c}\text { Масса } \\
\text { исходного, } \\
\Gamma\end{array}$ & $\begin{array}{c}\text { Масса ко- } \\
\text { нечного, г }\end{array}$ & $\begin{array}{c}\text { Убыль } \\
\text { веса, г }\end{array}$ & $\begin{array}{c}\text { Выход } \\
\text { огарка, \% }\end{array}$ & $\begin{array}{c}\text { Содержание } \\
\text { цинка в } \\
\text { огарке, \% }\end{array}$ \\
\hline 1 & 30 & 150 & 108,82 & 41,18 & 72,55 & 55,03 \\
\hline 2 & 60 & 150 & 107,63 & 42,37 & 71,75 & 55,35 \\
\hline 3 & 90 & 150 & 107,54 & 42,46 & 71,69 & 55,50 \\
\hline 4 & 120 & 150 & 107,32 & 42,68 & 71,54 & 56,30 \\
\hline 5 & 150 & 150 & 106,87 & 43,13 & 71,24 & 56,77 \\
\hline
\end{tabular}




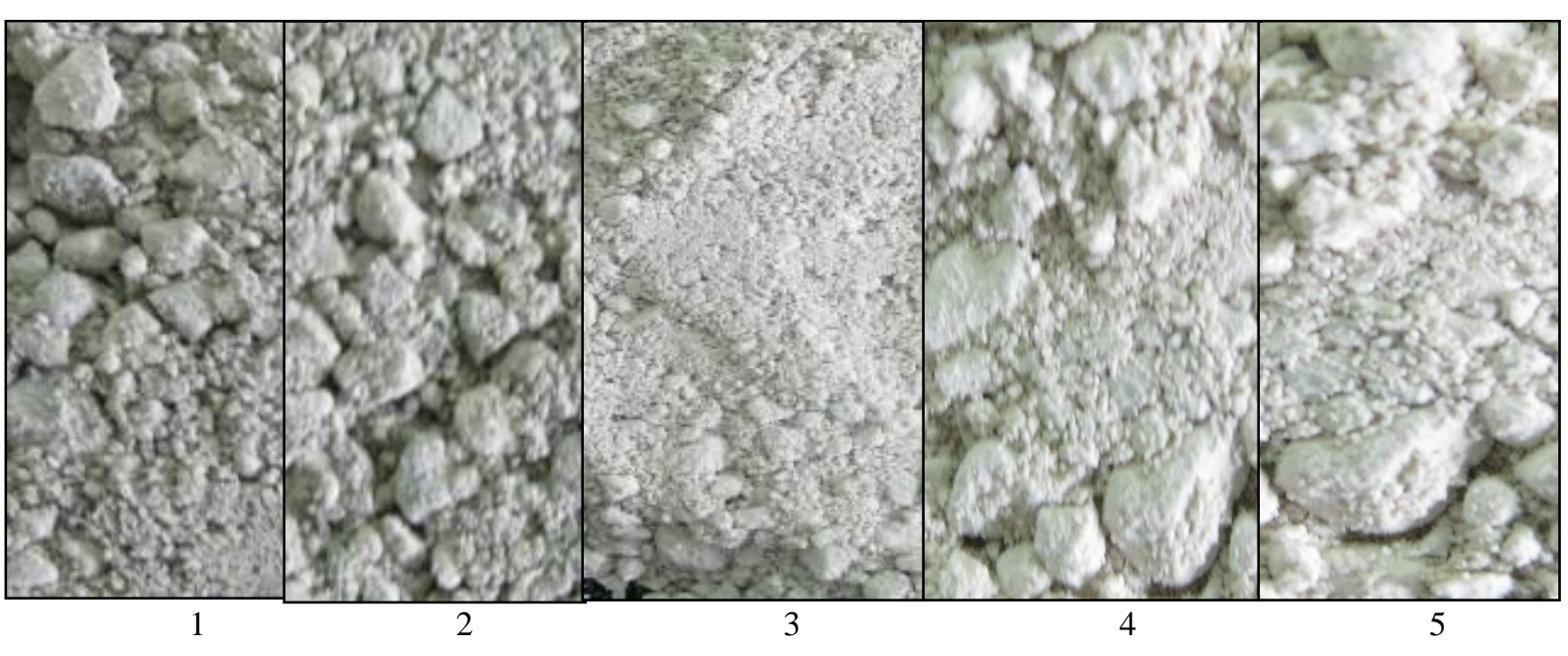

Время обжига: 1- 30 мин., 2 - 60 мин., 3 - 90 мин., 4 - 120 мин., 5 - 150 мин.

Рисунок 10 - Фотографии обожжённого карбонатного цинкового осадка

Как видно из данных таблицы 12, для обжига материала достаточно выдержки 30 минут, но при этом на поверхности и внутри частиц материала наблюдается почернение, с увеличением продолжительности обжига более 90 минут чернота исчезает. Наличие черноты может быть связано с присутствием в материале органической составляющей. Обжиг следующих порций карбонатного цинкового осадка осуществляли при регламентируемой продолжительности 0,5 часа. Карбонатный осадок, полученный в ходе испытаний, был обожжён и подготовлен для передачи Заказчику. Результаты химического анализа усреднённого обожженного цинкового осадка приведены в таблице 13.

Таблица 13 - Результаты химического анализа обожжённого карбонатного цинкового осадка

\begin{tabular}{|c|c|}
\hline Компонент & Содержание, $\%$ \\
\hline $\mathrm{Zn}$ & 64,2 \\
\hline $\mathrm{Ca}$ & 0,4 \\
\hline $\mathrm{Fe}$ & 0,17 \\
\hline $\mathrm{Cl}$ & 0,83 \\
\hline $\mathrm{Cu}$ & 0,03 \\
\hline $\mathrm{As}$ & $<0,03$ \\
\hline $\mathrm{Sb}$ & $<0,02$ \\
\hline $\mathrm{C}$ & 5,72 \\
\hline $\mathrm{S}$ & 0,15 \\
\hline
\end{tabular}

Максимальное достигнутое извлечение цинка по щелочному выщелачиванию шламов составило 92,4\%.
Выводы. Представлены результаты опытно-промышленных испытаний технологической схемы переработки цинксодержащих шламов сточных вод производства химволокна, в основе которой лежат процессы щелочного выщелачивания цинка. Проведенная в ходе стендовых испытаний серия опытов дала возможность изучить влияние температуры, соотношения компонентов, времени на выход продукта и подтверждает результативность разработанной технологической схемы.

\section{Список литературы}

[1] Г. С. Столяренко, та Г. М. Атамась, "Технологічний процес отримання цинкового купоросу із цинковмісних шламів", на VI Міжнар. наук.-практ. конф. Наука та інновації. Пшемисль, 2010.

[2] А. Г. Атамась, "Технологічний процесс отримання цинкового купоросу із цинковмісних шламів стічних вод", автореф. дис. ... канд. техн. наук. Черкаси, 2011.

[3] Г. С. Столяренко, В. О. Костигін, та Г. М. Атамась, "Спосіб отримання цинкового купоросу і кальцієвої селітри", декларачійний патент України 22213, МКИС22B19/00. № 200604768; Заявл. 28.04.2006; Опубл. 25.04.2007, Бюл. № 5,4 c.

[4] Г. М. Атамась, "Дослідження фізикохімічних властивостей цинковмісних шламів ВАТ «Черкаське хімволокно»" Вісник Черкаського державного техно- 
логічного університету, № 1, с. 135-138, 2006.

[5] Г. С. Столяренко, В. О. Костигін, та T. I. Семененко та ін., "Спосіб отримання цинкового купоросу", декларащійний патент України 5760, МКИ С 22 В 19/34. № 20040806824; Заявл. 13.08.2004; Опубл. 15.03.2005, Бюл. № 3, 4 с.

[6] Г. С. Столяренко, В. О. Костигін, Н. М. Фоміна, та ін. "Спосіб комплексної переробки цинковмісного шламу", декларачійний патент Украӥни 5759, МКИ С 22 В 19/34. № 20040806823; Заявл. 13.08.2004; Опубл. 15.03.2005, Бюл. № 3, 4 с.

[7] С. Д. Разумовский, и Г. Е. Заиков, Озон и его реакции с органическими соединениями. Москва: Наука, 1974.

[8] Г. М. Атамась, та Г. С. Столяренко, "Використання раціональних схем переробки відходів для вирішення екологічних проблем", Вісник Черкаського державного технологічного універcumemy, № 2, C. 106-109, 2008.

[9] Г. М. Атамась, та Г. С. Столяренко, "Використання озону для очищення лужних цинковмісних розчинів", Сучасні проблеми технології неорганічних речовин, № 2, с. 92-95, 2008.

[10] Г. М. Атамась, та Г. С. Столяренко, "Визначення умов взаємодії озону з цинковмісним розчином", на $I У_{\kappa р}$. конф. Реакиії окиснення. Наука і технологіі. Рубіжне, 2010, c. 84-85.

[11] Г. М. Атамась, "Можливість застосування промислових відходів у контексті переходу до збалансованого розвитку", Вісник національного технічного університету «XПI», № 10 , c. 52-56.

\section{References}

[1] H. S. Stolyarenko, and G. M. Atamas, "Technological process of obtaining zinc sulfate from zinc-containing sludge", in Proc. VI Internat. Sci. and Pract. Conf. Science and innovation. Przemysl, 2010 [in Ukrainian].

[2] A. G. Atamas, "Technological process of obtaining zinc sulfate from zinc-containing waste sludge from sewage", thesis for Ph. D. in Engineering. Cherkasy, 2011 [in Ukrainian].
[3] G. S. Stolyarenko, V. O. Kostigin, and G. M. Atamas, "Method for eliminating zinc vitriol and calcium sulfate", Declaration $\mathrm{Pa}$ tent of Ukraine 22213, MKIS22V19/00. no. 200604768; stated 28.04.2006; publ. 25.04.2007, Bul. № 5, 4 p. [in Ukrainian].

[4] G. M. Atamas, "Submission of physical and chemical power of zinc slurry of VAT "Cherkaske Khimvolokno»", Visnyk Cherkaskogo derzhavnogo tehnologichnogo universitetu, no. 1, pp.135-138, 2006 [in Ukrainian].

[5] G. S. Stolyarenko, V. O. Kostigin, T. I. Semenenko et al., "Method for the removal of zinc vitriol", Declaration Patent of Ukraine 5760, МКИ $C \quad 22 \quad$ В $19 / 34$, no. 20040806824; stated 13.08.2004; publ. 15.03.2005, Bul. no. 3, 4 p. [in Ukrainian].

[6] V. O. Stolyarenko, N. M. Kostigin, N M. Fomina et al., "Method for complex processing of zinc sludge", Declaration $\mathrm{Pa}$ tent of Ukraine 5759, МКИ С 22 В 19/34, no. 20040806823; stated 13.08.2004; publ. 15.03.2005, Bul. no. 3, 4 p. [in Ukrainian].

[7] S. D. Razumovsky, and G. E. Zaikov, Ozone and its reactions with organic compounds Moscow: Nauka, 1974 [in Russian].

[8] G. M. Atamas, and G. S. Stoliarenko, "The use of rational waste treatment schemes to solve environmental problems", VisnykCherkaskogo derzhavnogo tehnolo-gichnogo universitetu, no. 2, pp. 106-109, 2008 [in Ukrainian].

[9] G. M. Atamas, and G. S. Stolyarenko, "The use of ozone for the purification of alkaline zinc-containing solutions", Suchasni problemy tehnolohiyi neorhanichnyh rechovyn. Dneprodzerzhinsk: DDTU, no. 2, pp. 92-95, 2008 [in Ukrainian].

[10] G. M. Atamas, and G. S. Stoliarenko, "Determination of conditions of interaction of ozone with zinc-containing solution", in First Ukr. Conf. Oxidation reactions. Science and Technology. Frontier, 2010, pp. 84-85 [in Ukrainian].

[11] G. M. Atamas, "The possibility of using industrial waste in the context of the transition to balanced development", Visnyk Natsionalnoho tehnichnoho universytetu "KhPI", no. 10, pp. 52-56 [in Ukrainian]. 


\section{G. S. Stolyarenko, T. S. Cherniy, N. M. Fomina, A. I. Shmorgun \\ HYDROMETALLURGICAL TECHNOLOGY OF PROCESSING OF ZINC-CONTAINING WASTEWATER SLUDES OF CHEMICAL FIBER PRODUCTION}

The introduction of sludge recycling technologies will free up the area occupied by sludge storage facilities, eliminate the cost of building new sludge and profit from the extraction of valuable components. Such, for example, is zinc, whose content in natural raw materials is 1-3\%, and in the waste of the production of viscose fiber $6.5-40 \%$ (depending on the range of products, and reagents used for wastewater treatment). Zinc-containing sludge at medium-sized enterprises is 1,000,000 tons, allowing it to process that amount of sludge with a capacity of 10 tons per hour for 10 to 15 years.

The paper presents a study of hydrometallurgical method of processing zinc-containing sewage sludge by leaching. The removal of zinc from the sludge is carried out on a semi-industrial installation. To study the particle size distribution of the source ore, wet sieving method is chosen. Phase chemical analysis on the forms of zinc is carried out. Also, X-ray and thermogravimetric analyzes are applied to study the real composition of the sample. On the basis of a series of experiments on a semi-industrial installation, the main stages of technological process are identified and investigated. According to the results of the research, the technological process of obtaining zinc sulfate from zinc-containing sludge production of viscose fiber is developed. It is proposed to divide the process into separate stages, in order to develop a flexible technological scheme, which allows the processing of different raw materials. For complete and effective extraction of zinc, the insoluble residue after the leaching step is proposed to be treated with a nitric acid solution, which allows to obtain an additional product - calcium nitrate enriched with micro-impurities. According to preliminary ecological and economic calculations, the profit from the sludge processing for one year will be about EUR 1.684 million. Through the implementation of the proposed scheme for the use of secondary products, a significant social effect is achieved by improving the environmental situation by reducing the amount of waste in the sludge collectors, creating jobs.

Keywords: leaching, zinc, sludge, semi-industrial installation, social effect, environmental-economic calculations.

\section{Г. С. Столяренко, Т. С. Черній, Н. М. Фоміна, А. І. Шморгун ГІДРОМЕТАЛУРГІЙНА ТЕХНОЛОГІЯ ПЕРЕРОБКИ ЦІНКОВМІСНИХ ШЛАМІВ СТІЧНИХ ВОД ВИРОБНИЦТВА ХІМВОЛОКНА}

Вилучення иинку зі шламу є актуальним для Украӥни з огляду на екологічну безпеку, а також для сфери виробнищтва добрив для аграрних країн. Великі площі иламу, що зберігається, становлять загрозу забруднення трунту, трунтових вод та посівів, i, відповідно, становлять значний ризик для людини та інших живих організмів. У статті представлено дослідження гідрометалургійного способу переробки цинковмісних шиламів стічних вод виробництва хімволокна шляхом вилуговування.

У попередніх роботах в лабораторії було встановлено фізичні та хімічні закони переробки осаду ицинку, розроблено технологічний процес утилізації мулу шляхом переробки иинковмісних сполук на сульфат иинку, досліджено склад та фізико-хімічні властивості осаду, що містить иинк, визначено умови обробки та раціональні способи утилізації, досліджено вплив температури на тривалість контакту, концентрацію реагенту, інтенсивність перемішування для процесу вилучення гідроксиду иинку. Проведена в ході стендових досліджень серія дослідів, а також виконані порівняльні техніко-економічні обтрунтування підтверджують результативність розробленої технологічної схеми.

Видалення циинку з циинковмісного мулу з виробництва віскозного волокна проводиться на напівпромисловій установиі. На основі серії експериментів на напівпромисловій установиі визначені та досліджені основні етапи технологічного прочесу. За результатами досліджень розроблено технологічний прочес одержання сульфату иинку з мулу. Пропонується розділити прочес на окремі етапи, щоб розробити гнучку технологічну схему, яка дозволяе переробляти різну сировину. Для повного та ефективного вилучення иинку нерозчинний залишок після етапу вилуговування пропонується обробити розчином азотної кислоти, що дозволяє отримати додатковий продукт - нітрат кальиію, збагачений мікродомішками.

Впровадження технології переробки мулу звільнить площу, щьо займають сховища мулу, позбавить витрат на будівництво нових сховищ для мулу та дасть прибуток від видобутку иінних компонентів. За попередніми еколого-економічними розрахунками, прибуток від переробки мулу за один рік становитиме близько 1,684 млн євро.

Ключові слова: вилуговування, иинк, илам, напівпромислова установка, соиіальний ефект, еколого-економічні розрахунки.

Стаття надійшла 19.08.2019

Прийнято 09.09.2019

(C) Г. С. Столяренко, Т. С. Черний, Н. М. Фомина, А. И. Шморгун, 2019 DOI: 10.24025/2306-4412.3.2019.178607 